\title{
Effects of Cut off the Irrigation in Different Growth Stages on Yield and Yield Components of Rapeseed Cultivars
}

\author{
Ali Soleymani ${ }^{1} \&$ Mohamad Hesam Shahrajabian ${ }^{1}$ \\ ${ }^{1}$ Department of Agronomy and Plant Breeding, Khorasgan Branch, Islamic Azad University, Esfahan, Iran \\ Correspondence: Ali Soleymani, Department of Agronomy and Plant Breeding, Khorasgan Branch, Islamic Azad \\ University, Esfahan, PO Box 81595-158, Iran. E-mail: a_Soleymani@khuisf.ac.ir
}

Received: June 14, 2012 Accepted: July 22, 2012 Online Published: September 21, 2012

doi:10.5539/ijb.v4n4p75 URL: http://dx.doi.org/10.5539/ijb.v4n4p75

\begin{abstract}
Iran is a country of water scarcity due to general low precipitation, high evaporation and the temporal and spatial distribution of rainfall. In order to determine the effects of disruption of irrigation in different growth stages of autumn's rapeseed cultivars, an experiment was conducted in 2009-2010 at Isfahan agriculture research station. A split plot layout within a randomized complete block design 3 replications was used. Main plots were seven levels of cut off irrigation namely, D1= current irrigation or irrigation after 80 millimeter vaporize from class $\mathrm{A}$ basin to physiological maturity, D2= cut off irrigation from stem elongation phase and then on, D3= cut off the irrigation from flowering and then on, D4= cut off the irrigation from pod formation phase and then on, D5= cut off the irrigation in stem and flowering phase, D6= cut off the irrigation in stem and pod phase, D7= cut off the irrigation in flower and pod formation, and sub plots were two rapeseed cultivars, namely, Zarfam and Okapi. With increasing the number of irrigation, rapeseed yield will increase, but if the water lacks occurred, it is better not to cut off irrigation in flower and stem phase, in order to get acceptable seed and oil yield. Zarfam had the highest oil and seed yield in withheld irrigation conditions and also have the best adaptation in water deficit conditions.
\end{abstract}

Keywords: irrigation, yield and yield components, rapes seed, cultivars

\section{Introduction}

Rapeseed oil is known as an important source of health-related compounds in the human diet (Harbaum-Piayda et al., 2010). Many arid and semi arid regions of the world need to implement on-farm water management, to meet the water conservation, sustainable food production, farm profitability, and environmental quality (Brian et al., 2002; Zhang et al., 2007). Limited irrigation controls soil water deficit at certain stages of crop growth and is a very important practice in recent years in place where water resources are limited (Fabeiro et al., 2002). Richter et al., (2010) reported that rapeseed (Brassica napus) oils differing in cultivars and sites of growth. Naeemi et al. (2007) concluded that withholding irrigation treatment decreased secondary branches number ( $8 \%$ ), silique number per plant $(31 \%)$, grain yield $(29 \%)$ and oil yield $(28 \%)$, whereas had not significant effect on plant height, silique height and 1000 seed weight. However, drought is one of the major constrain to agricultural production under semi arid climatic condition of Esfahan. This study aimed to evaluate the effect of disruption of irrigation on yield and yield components of autumn's rapeseed cultivars in a semi-arid area of Isfahan province, Iran, to provide some information on how to manage irrigation during various crop growth stages.

\section{Materials and Methods}

In order to evaluate the effects of cut off irrigation in different growth stages of autumn's rapeseed cultivars, an experiment was conducted in 2009-2010 at Esfahan agriculture research station (Latitude $32^{\circ} 30^{\prime}$ N, Longitude $51^{\circ} 49^{\prime} \mathrm{E}$, and $1541 \mathrm{~m}$ elevation). A split plot layout within a randomized complete block design 3 replications was used. Main plots were seven levels of cut off irrigation namely, D1= current irrigation or irrigation after 80 millimeter vaporize from class A basin to physiological maturity, D2= cut off irrigation from stem elongation phase and then on, D3= cut off the irrigation from flowering and then on, D4= cut off the irrigation from pod formation phase and then on, D5= cut off the irrigation in stem and flowering phase, D6= cut off the irrigation in stem and pod phase, D7= cut off the irrigation in flower and pod formation, and sub plots were two rapeseed cultivars, namely, Zarfam and Okapi. Soil texture was clay loam. Long term average precipitation was $150 \mathrm{~mm}$. Soil fertilizer was used on the basis of plant's need. Plots were $7 \mathrm{~m}$ long with 6 rows spaced $24 \mathrm{~cm}$ apart. The 
distances for main plots in order to fertilizer treatment were $2 \mathrm{~m}$. The seeds were seeded on 1 November. Harvest index was computed as the ration of the seed yield to aboveground dry matter at harvest. Oil content was determined by nuclear magnetic resonance analyzer (NMR) (Omidi et al., 2010). Analysis of variance (ANOVA) was used to determine the significant differences. The Multiple Range Test of Duncan performed the separation means. All statistics was performed with MSTAT-C program (version 2.10).

\section{Results and Discussion}

The effects of cut off the irrigation was significant on the number of pods per plant, the number of seed per pod, a thousand seed yield, seed yield, biological yield, harvest index and oil yield. Cultivars also had significant influence on all experimental traits. The number of pods per plant influenced by interaction between disruption of irrigation and cultivar (Table 1). To produce adequate seed and oil yield, irrigation must be done at two vital growth stages, namely stem elongation and flowering stage. Naeemi et al. (2007) also reported that withheld of irrigation trait had undesirable effects on yield of rapeseed cultivars. The results of this experiment indicated that provide of sufficient water at the terminal stages of reproductive growth have specially importance to obtain high grain and oil yield. When plants encounter water deficit, there is a decline in photosynthesis, this can be due to a reduction in light interception as leaf expansion is reduced or as leaf senescence is accelerated (Block et al., 2006). Khomari et al. (2008) also reported that watering at flowering stage is the most important parameter for improving sunflower grain yield. Generally, Zarfam cultivar in all mentioned qualities had main different with Okapi cultivar. Zarfam had the highest oil yield in withheld irrigation conditions and also have the best adaptation in water deficit conditions. Naeemi et al. (2007) demonstrated that the highest seed yield in water deficit conditions was produced in Opera and Zarfam cultivars, $(2058 \mathrm{~kg}$ per ha) and (1896 kg per ha), respectively. Zarfam seed yield and oil yield was $3413 \mathrm{~kg} / \mathrm{ha}$ and $1543.8 \mathrm{~kg} / \mathrm{ha}$, respectively (Table 2). Increasing knowledge about irrigation interval and vital rapeseed growth stages in irrigated agriculture play a significant role in maintaining food security (Deng et al., 2006).

Table 1. Analysis of variance the number of pods per plant, the number of seed per pod, a thousand seed yield, seed yield, biological yield, harvest index, oil percentage, oil yield

\begin{tabular}{|c|c|c|c|c|c|c|c|c|c|}
\hline S.O.V & d.f. & $\begin{array}{l}\text { The } \\
\text { number } \\
\text { of pods } \\
\text { per } \\
\text { plant }\end{array}$ & $\begin{array}{c}\text { The } \\
\text { number } \\
\text { of seed } \\
\text { per pod }\end{array}$ & $\begin{array}{c}\text { A } \\
\text { thousand } \\
\text { seed } \\
\text { weight }\end{array}$ & Seed yield & $\begin{array}{c}\text { Biological } \\
\text { yield }\end{array}$ & $\begin{array}{l}\text { Harvest } \\
\text { index }\end{array}$ & $\begin{array}{c}\text { Oil } \\
\text { percentage }\end{array}$ & Oil yield \\
\hline Replication & 2 & 15.92 & $9.5^{*}$ & 0.019 & 906.7 & 109810.7 & 0.0001 & 5.062 & 5955.5 \\
\hline $\begin{array}{c}\text { Cut off } \\
\text { irrigation }\end{array}$ & 6 & $670.77^{* *}$ & $162.413^{* *}$ & $0.813^{* *}$ & $5359312.3^{* *}$ & $78356362.2^{* *}$ & $0.001^{* *}$ & 1.098 & $1038643.6^{* *}$ \\
\hline Error (a) & 12 & 5.734 & 1.722 & 0.027 & 19621.9 & 1498972.8 & 0.0001 & 3.555 & 8991.4 \\
\hline Cultivar & 1 & $123.42^{* *}$ & $59.524^{* *}$ & $0.482^{* *}$ & $418601.2^{* *}$ & $49060105.9^{* *}$ & $0.002^{* *}$ & $17.357^{*}$ & $181897.5^{* *}$ \\
\hline $\begin{array}{c}\text { Cut off } \\
\text { irrigation } \times \\
\text { cultivar }\end{array}$ & 6 & $3.817^{*}$ & 1.079 & 0.0005 & 2102.2 & 181036.3 & 0.0001 & 1.958 & 1366.6 \\
\hline Error (b) & 14 & 1.333 & 0.5 & 0.003 & 8131.6 & 218279.6 & 0.001 & 2.585 & 3876.7 \\
\hline
\end{tabular}

\footnotetext{
* significant at 0.05 significance in F-tests;

${ }^{* *}$ significant at 0.001 significance in F-tests.
} 
Table 2. Mean comparison of the number of pods per plant, the number of seed per pod, a thousand seed yield $(\mathrm{g})$, seed yield $(\mathrm{kg} / \mathrm{ha})$, biological yield $(\mathrm{kg} / \mathrm{ha})$, harvest index (\%), oil percentage, oil yield $(\mathrm{kg} / \mathrm{ha})$

\begin{tabular}{|c|c|c|c|c|c|c|c|c|}
\hline Treatment & $\begin{array}{l}\text { The } \\
\text { number } \\
\text { of pods } \\
\text { per plant }\end{array}$ & $\begin{array}{c}\text { The } \\
\text { number } \\
\text { of seed } \\
\text { per pod }\end{array}$ & $\begin{array}{c}\text { A } \\
\text { thousand } \\
\text { seed } \\
\text { weight }\end{array}$ & $\begin{array}{l}\text { Seed } \\
\text { yield }\end{array}$ & $\begin{array}{l}\text { Biological } \\
\text { yield }\end{array}$ & $\begin{array}{c}\text { Harvest } \\
\text { index }\end{array}$ & $\begin{array}{c}\text { Oil } \\
\text { percentage }\end{array}$ & $\begin{array}{c}\text { Oil } \\
\text { yield }\end{array}$ \\
\hline \multicolumn{9}{|l|}{ Irrigation } \\
\hline $\begin{array}{l}\text { Current } \\
\text { irrigation } \\
\text { (control) }\end{array}$ & $78.67 \mathrm{a}$ & $37.83 a$ & $3.917 \mathrm{a}$ & $4838 \mathrm{a}$ & $20540 a$ & $18.8 \mathrm{a}$ & $44.2 \mathrm{a}$ & $2138 a$ \\
\hline $\begin{array}{l}\text { Cut off } \\
\text { irrigation } \\
\text { from stem } \\
\text { elongation }\end{array}$ & $45.33 \mathrm{e}$ & $22.17 \mathrm{e}$ & $3.067 \mathrm{de}$ & $1993 \mathrm{e}$ & $10960 \mathrm{e}$ & $15.5 \mathrm{c}$ & $44 a$ & $877.5 \mathrm{e}$ \\
\hline $\begin{array}{l}\text { Cut off } \\
\text { irrigation } \\
\text { from } \\
\text { flowering }\end{array}$ & $51.67 \mathrm{~d}$ & $25.5 \mathrm{~d}$ & $3.4 \mathrm{~b}$ & $2529 d$ & $11310 \mathrm{e}$ & $18.5 \mathrm{a}$ & $45.1 \mathrm{a}$ & $1140 d$ \\
\hline $\begin{array}{l}\text { Cut off } \\
\text { irrigation } \\
\text { from pod } \\
\text { formation }\end{array}$ & $62 b$ & $30 \mathrm{c}$ & $2.867 \mathrm{e}$ & $2798 \mathrm{c}$ & $13480 \mathrm{~d}$ & $17.2 \mathrm{~b}$ & $45.2 \mathrm{a}$ & $1264 c$ \\
\hline $\begin{array}{l}\text { Cut off } \\
\text { irrigation } \\
\text { in stem } \\
\text { and } \\
\text { flowering } \\
\text { stage }\end{array}$ & $56.17 \mathrm{c}$ & $30.83 c$ & $3.733 a$ & $3764 b$ & $18600 \mathrm{~b}$ & $16.8 b$ & $44.7 \mathrm{a}$ & $1682 b$ \\
\hline $\begin{array}{l}\text { Cut off } \\
\text { irrigation } \\
\text { in stem } \\
\text { and pod } \\
\text { formation }\end{array}$ & $64.17 \mathrm{~b}$ & $34.33 b$ & $3.317 \mathrm{bc}$ & $3649 b$ & $16720 \mathrm{c}$ & $18 \mathrm{ab}$ & $44.6 \mathrm{a}$ & $1630 \mathrm{~b}$ \\
\hline $\begin{array}{l}\text { Cut off } \\
\text { the } \\
\text { irrigation } \\
\text { in flower } \\
\text { and pod } \\
\text { formation }\end{array}$ & $58 \mathrm{c}$ & $30.33 c$ & $3.183 \mathrm{~cd}$ & $3622 b$ & $15300 \mathrm{c}$ & $19.2 \mathrm{a}$ & $44.6 \mathrm{a}$ & $1615 b$ \\
\hline \multicolumn{9}{|l|}{ Cultivar } \\
\hline Okapi & $57.714 \mathrm{~b}$ & $28.952 b$ & $3.248 b$ & $3213 b$ & $14192 b$ & $18.4 \mathrm{a}$ & $43.9 b$ & $1412.2 \mathrm{~b}$ \\
\hline Zarfam & $61.143 a$ & $31.333 \mathrm{a}$ & $3.642 \mathrm{a}$ & $3413 a$ & $16354 a$ & $17.0 \mathrm{~b}$ & $45.2 \mathrm{a}$ & $1543.8 \mathrm{a}$ \\
\hline
\end{tabular}

Common letters within each column do not differ significantly.

\section{Conclusions}

Generally, with increasing the number of irrigation, rapeseed yield will increase, but if the water lacks occurred, it is better not to cut off irrigation in flower and stem phase, in order to get acceptable seed and oil yield.

\section{References}

Block, D., Hoffmann, C. M., \& Marlander, B. (2006). Impact of water supply on photosynthesis, water use and carbon isotope discrimination of sugar beet genotypes. European Journal of Agronomy, 24, 218-225. 
http://dx.doi.org/10.1016/j.eja.2005.08.004

Brian, G. L., Mary, H., Todd, E., \& Gary, M. (2002). Adoption and adaptation of scientific irrigation scheduling: Trends from Washington, USA as of 1998. Agric. Water Manage, 55, 105-120. http://dx.doi.org/10.1016/S0378-3774(01)00191-3

Deng, X. P., Shan, L., Zhang, H., \& Turner, N. C. (2006). Improving agricultural water use efficiency in arid and semi-arid areas of China. Agric. Water Manage, 80, 23-40. http://dx.doi.org/10.1016/j.agwat.2005.07.021

Fabeiro, C., Martin de Santa Olalla, F., \& de Juan, J. A. (2002). Production of muskmelon (Cucumis melo L.) under controlled deficit irrigation in a semi-arid climate. Agric. Water Manage, 54, 93-105. http://dx.doi.org/10.1016/S0378-3774(01)00151-2

Harbaum-Piayda, B., Oehlke, K., Sonnichsen, F. D., Zacchi, P., Eggers, R., \& Schwarz. K. (2010). New polyphenolic compounds in commercial deodistillate and rapeseed oils. Food Chemistry, 123, 607-615. http://dx.doi.org/10.1016/j.foodchem.2010.04.078

Khomari, S., Ghasemi Golezani, K., Aliari, H., Zehtab Salmasi, S., \& Dabagh Mohamadi nasab, A. (2008). Effect of irrigation disruption on phenology and grain yield of three sunflower (Helianthus annuus L.) cultivars in Tabriz. Journal of Agriculture Science and Natural Resources (in Farsi), 14(6), 210-218.

Naeemi, M., Akbari, G. H., Shirani Rad, A. H., Modares Sanavi, A. M., \& Sadat Nuri, A. (2007). Investigation of some morphological and agronomical traits of rapeseed cultivars in response to withheld irrigation at reproductive growth stages. Agriculture Research: Water, Soil and Plant in Agriculture (in Farsi), 7(13), 223-233.

Omidi, H., Tahmasebi, Z., Naghdi Badi, H. A., Torabi, H., \& Miransari, M. (2010). Fatty acid composition of canola (Brassica napus L.), as affected by agronomical, genotypic and environmental parameters. Comptes Rendus Biologies, No of pages 7.

Richter, E. K., Spangenberg, J. E., Kreuzer, M., \& Leiber. F. (2010). Characterization of rapeseed (Brassica napus) oils by bulk $\mathrm{C}, \mathrm{O}, \mathrm{H}$, and fatty acid stable isotope analyses. Journal of Agricultural and Food Chemistry, 58(13), 8084-8055. http://dx.doi.org/10.1021/jf101128f

Zhang, B. C., Huang, G. B., \& Li, F. M. (2007). Effect of limited single irrigation on yield of winter wheat and spring maize relay intercropping. Pedosphere, 17(4), 529-537. http://dx.doi.org/10.1016/S1002-0160(07)60063-0 